\title{
KorONAVÍRUS ÉS OKTATÁSPOLITIKA
}

\author{
NAHALKA IST VÁN
}

Beérkezett: 2020. december 16., elfogadva: 2021. január 13.

\begin{abstract}
A COVID-19-járvány számos nehezen megoldható feladatot jelentett a magyar oktatásirányítás számára is. Ma még nem áll rendelkezésre kellő mennyiségű konkrét ismeret annak eldöntésére, hogy a szigorúbb intézkedések jelentősen hozzájárulnak-e a járvány hatásainak enyhítéséhez. Az oktatás folyamatossága biztosításának legfontosabb feltétele, hogy az oktatási rendszerben domináns szerepet játsszon a korszerü pedagógiai kultúra. Magyarországon ez a feltétel nem áll rendelkezésre, ennek okait az oktatáspolitikában kell keresni. Az esélyegyenlőtlenségek növekedése az egész világon jelentős volt, így hazánkban is. Az iskolabezárások a hátrányos helyzetű tanulók esetében okoztak jelentősebb tanulási elmaradásokat. Az oktatáspolitikának és az oktatásirányításnak nem volt válasza erre a súlyos problémára.
\end{abstract}

Kulcsszavak: oktatáspolitika, iskolabezárás, az oktatás folyamatossága, esélyegyenlőtlenség, pedagógiai kultúra, az oktatás modernizációja

In the course of COVID-19 epidemic the Hungarian educational government also had numerous challenges. Today we have not enough concrete knowledge to say that hard measures are conductive to mitigate the effects of the epidemic or not. The most important condition of the continuation of education is the dominant role of the modern pedagogical culture in the educational system. In Hungary this condition is not ready. The causes of this situation we have to seek in the educational policy. The rising of inequality of opportunity was appreciable on the whole World, in our country too. The closures of schools caused more significant lagging in learning processes and outcomes in the case of handicapped students. Educational policy and administration had no any answer to this serious problem.

Keywords: educational policy, school closure, continuation of education, inequality of opportunity, pedagogical culture, modernalization of education

\footnotetext{
A 2019-ben elindult koronavírus-járvány az oktatási rendszereket megbénító legjelentősebb esemény az emberiség történetében, ahogy nagyon sok oktatási szakember fogalmaz (pl. Lancker-Parolin 2020; Jakab 2020; Birnbaum 2020). Ha nem is feltétlenül fogadja el mindenki ezt az állítást, azonban az kétségtelen, hogy az oktatásnak a pandémia alatt, és valószínüleg majd azt követően is, nagyon komoly kihívásokkal kellett és kell szembenéznie.
} 
E tanulmány a koronavírus-járvány hazai oktatáspolitikai tanulságaival foglalkozik. Sajátossága, hogy folyamat közben kíván egy részterületről látleletet adni, ezért kijelentései nem véglegesek, csak a kb. 2020 novemberéig történtekről szólhatnak, és a tények és adatok jóval kisebb tömegére épülhetnek, mint az egy vagy akár több év múlva készülö összegzések. Kijelentéseim tehát - miközben maximálisan törekszem állításaim bizonyítékokkal történő alátámasztására - több esetben is közelebb állnak a feltételezéshez. Egy nagyon összetett helyzet elemzése során keresem az értelmezési kereteket.

A Föld országaiban az oktatási rendszerek irányítói a járvány kezdetén első megközelítésben ugyanazon feladatokat kellett, hogy megoldják:

- Döntéseket kellett hozni az oktatási intézmények jelenléti vagy távolléti oktatásával, és bezárás esetén a digitális munkarend bevezetésével kapcsolatban.

- Mindent meg kell tenni azért, hogy az oktatás folytatódjék.

- Komoly lépésekre volt, van szükség a várható, illetve a már bekövetkezett oktatási esélyegyenlőtlenség-növekedés mérséklésére.

Ezek természetesen csak a kiemelkedő, de a médiában zajló kommunikációban, valamint a szakirodalomban is a leggyakrabban megjelenő oktatásigazgatási feladatok, e tanulmányban magam is csak e három kérdéskörrel foglalkozom. ${ }^{1}$

\section{„Iskolabezárás”}

$\mathrm{A} z$ Unesco COVID-19-járvánnyal kapcsolatos programjának, a Global Education Coalition-nak egy becslése szerint a pandémia a világban mintegy másfél milliárd gyermek és fiatal, 63 millió pedagógus életét befolyásolta alapvetően. ${ }^{2}$ Szintén az Unesco müködtet egy olyan weboldalt, amelyen 2020 februárjától az aktuális napig követhető nyomon, hogy a Föld országaiban hány iskolai tanuló, felsőoktatási hallgató volt érintett az iskolabezárásokban, ők százalékosan mekkora hányadát képviselik az összes tanulónak, és még azt is megtudhatjuk, hogy a kezdetektől indulva az egyes időpontokban melyik ország milyen státusszal volt jellemezhető (teljes zárás, részlegesen nyitott, teljesen nyitott, éppen iskolai szünet van). ${ }^{3}$ Azt látjuk, hogy amikor Magyarországon 2020. március 13-án a kormány bejelentette az iskolák bezárását és az áttérést a távolléti oktatásra, akkor a Földön az oktatási intézményekbe járóknak már 43\%-a volt hasonló helyzetben. Még annak a hónapnak a végére érte el ez az arány a $84 \%$ körüli maximumát. A térkép szinte egyszínű volt ekkor, a Föld legtöbb országában bezárták az iskolákat.

A második hullám gyökeresen más képet mutat. E sorok írásakor, december elején az adatok azt mutatják, hogy a tanulóknak csak $18 \%$-a érintett az iskolabezárásban. Az első hullámban Magyarországon minden oktatási-nevelési intézményt, minden pedagógust

1 Természetesen még számos - önmagukban jelentős - kérdéssel kellett foglalkoznia a szakpolitikának, például a távolléti oktatás jóléti, szociális, valamint pszichés következményeivel, az oktatásnak nem tanórai rendben zajló aktuális feladataival (érettségi, más vizsgák, önkéntes munka, felvételik stb.), egészségvédelemmel összefüggő intézkedéseket kellett hozni. Az UNESCO (2020) egy rövid ajánlása számos olyan oktatási problémát sorol fel, amelyek a COVID-19-válság hatására alakultak ki, és amelyek szakpolitikai szintü beavatkozásokat is igényeltek.

2 https://en.unesco.org/news/unesco-showcases-education-responses-coviD-19-crisis-general-assembly [Letöltve: 2020. 08. 17.]

3 https://en.unesco.org/covid19/educationresponse [Letöltve: 2020. 10. 05.] 
és gyermeket, tanulót, hallgatót érintettek az intézkedések, a második hullámban december 7-ig csak a felsőfokon és a középfokú oktatásban történt meg a távolléti oktatás elrendelése.

Általános megítélés szerint Magyarország a COVID-19-járvány első hullámában felmerült problémákat jól kezelte, az elsődlegesnek tekintett járványügyi adatok nagyon sok országhoz viszonyítva hazánkban sokkal jobban alakultak. Bár ma még e kérdésben a végső szó nem mondható ki, de felmerül, hogy ez az eredmény a viszonylag korán meghozott szigorú intézkedéseknek, s köztük az oktatási intézményrendszerben a jelenléti oktatás 2020. március 13-án eldöntött teljes leállításának volt köszönhető. Az intézkedés meghozatalakor már világos volt, hogy a szigorúságnak súlyos ára lesz elsősorban gazdasági területeken. A gazdaság müködését természetesen a járvány többféle módon is befolyásolta, de ezek közül az egyik jelentős tényező maga az iskolabezárás volt. A kisebb gyerekek szüleinek (legalább az egyik szülőnek) otthon kellett maradniuk a gyerekekkel, és ezzel sokan kiestek a munkából. A gazdaság természetesen konkrét károkat szenvedett a munkaerő kiesése következtében, és ha nem is ez volt az egyetlen tényező, talán nem is a legnagyobb hatású, de komoly szerepet játszhatott abban, hogy 2020 márciusától kezdődően a gazdasági termelés jelentős mértékben visszaesett.

A COVID-19-járvány második hullámára a jelenléti oktatás leállításával kapcsolatos politika jelentős mértékben megváltozott. November hónapban - ekkor a járványnak tulajdonítható halálesetek napi száma már jelentős mértékű növekedést mutatott - a kormány csak közép- és felsőfokon állította le a jelenléti oktatást. Tavasszal, az első hullám esetén, s legutóbb, a második hullámban, ősszel is a politikának azt kellett mérlegelni, hogy mely területen kockáztat inkább: a gazdaságban vagy az egészségügyben. A választás az egészségügyre esett, az oktatás közép- és felsőfokon tért csak át a digitális munkarendre.

A tavaszi és az őszi általános intézkedéscsomag valójában nagyon hasonló (a kijárás korlátozása, üzletek, szórakozóhelyek bezárása, rendezvények tartásának tiltása, az idősek védelme vásárlási sáv bevezetésével stb.). A jelentős különbség a kettő között éppen a jelenléti oktatás megszüntetésében mutatható ki. Logikusan merül fel a kérdés, hogy ilyen körülmények között milyen szerepe volt a bölcsődék, az óvodák és az általános iskolák változatlan működtetésének abban, hogy Magyarországnak a járvány második szakaszában a fertőzésszámokkal, kórházi kezelésekkel kapcsolatos, és különösen a fertőzés következtében elhunytak számában mérhető adatai lényegesen rosszabbak, mint az első hullámban. November közepére, végére oda jutottunk, hogy az európai országok között a lakosság létszámához viszonyított, a COVID-19-járványnak betudható egy heti halálesetek arányában a mi adataink a 3-5. legrosszabbak (a Johns Hopkins Egyetem járványügyi adatai alapján számolva $\left.{ }^{4}\right)$.

Mielőtt túl gyorsan döntenénk arról, hogy a hazai pandémiás helyzet igencsak aggasztó voltát egyértelmüen annak tudjuk be, hogy a kormányzat nem zárta be a bölcsődéket, az óvodákat és az általános iskolákat, szögezzük le, hogy a rossz adatokat nem csak ez a tényező okozhatja. Nem vagyok járványügyi szakember, ezért csak a lehetöségét vetem fel más megfontolásoknak. Az egyik lehetséges további (és az előbbit nem kizáró) magyarázat az, hogy Magyarországon ősszel az intézkedések túl későn születtek meg. Elképzelhető, hogy a nevelési, oktatási intézmények hozzájárulása a vírus terjedé-

4 https://coronavirus.jhu.edu/map.html [Letöltve: 2020. 11. 29.] 
séhez nem különösebben jelentős, és a bölcsődék, az óvodák, valamint az általános iskolák bezárása nem sokat javított volna a helyzeten. Ma még ezt nem tudhatjuk. Továbbá az is elképzelhető, hogy a vírus jelentős elterjedését valójában már a "nagy nyári nyitás" megalapozta, és elsősorban a fiatalok körében terjedt a fertőzés anélkül, hogy komoly számban jelentkeztek volna megbetegedések. Majd a nagyszámú fertőzött, de tüneteket nem mutató fiatal fokozatosan elterjesztette a vírust az idősebb, már nem teljesen egészséges honfitársaink körében is, és ez a folyamat „robbantotta be” a tömeges megbetegedést. Bocsánatot kérek, hogy teljes mértékben szakmán kívüliként megengedek magamnak ilyen gondolatmeneteket, de csak arra szerettem volna felhívni a figyelmet, hogy bár a tavaszi és az őszi intézkedések között valóban a leglényegesebb különbség a jelenléti oktatás eltérő mértékű megszüntetése, ebből nem következik egyenesen, hogy a járvány súlyos következményeiért ez az intézkedés, annak korlátozott jellege a felelős. De azt sem zárhatjuk ki, hogy igen, mégis jelentős mértékben felelős. Kíváncsian várjuk a szakemberek bizonyítékokon alapuló elemzésének eredményeit e kérdésben is.

A kérdésről egyébként is vita folyik, és rendkívül eltérő megoldásokat alkalmaznak az országok. Vita van kibontakozóban azzal kapcsolatban, hogy az iskolarendszerüket nem bezáró országokban vajon az oktatási intézmények hozzájárulnak-e jelentős mértékben a járvány terjedéséhez, illetve fordítva, hogy vajon az iskolabezárás egy országban jól érzékelhető mértékben lassítja-e a járvány terjedését. Nagyon kevés adat áll rendelkezésre ennek megítéléséhez. A korábbi eseteket (pl. H1N1 vagy az influenzavírus terjedése) feldolgozó szakirodalomban általában pozitív hatást tulajdonítanak az elvégzett számítások alapján az iskolabezárásoknak (erre nézve lásd pl.: Holle 2020; Jackson et al. 2014). Finnországban 20000 diák és pedagógus karanténba vonulását kellett elrendelni a teljes 1,2 milliós létszámból, s a karanténba kerülőknek is csak 1\%-a, 200 fő bizonyult pozitívnak a teszteléskor (Birnbaum 2020). Egy az Egyesült Államok 50 államában folytatott, kiterjedt vizsgálat ellenben azt találta, hogy az iskolabezárás (amely az első hullámban március hónapban minden államban bekövetkezett) jelentős mértékben enyhítette a problémákat (amelyek, mint tudjuk, még így is igen súlyosak voltak, és súlyosak ma is az Egyesült Államokban). Az iskolabezárásokat követően jelentős mértékben csökkent a napi új, ismertté vált fertőzések, illetve a halálesetek száma is (Auger et al. 2020). A Johns Hopkins Egyetem COVID oldalán (lásd 4. lábjegyzet) ez a változás jól látható is március közepét követően az Egyesült Államok adatain. Ugyanakkor a szerzők is megjegyzik, hogy csak az összefüggést tudták kimutatni, az esetek csökkenésében természetesen más intézkedések is szerepet játszhattak. Hozzáteszem, országonként, de legalábbis „kultúránként” akár jelentős mértékben eltérhetnek egymástól a folyamatok. Most jó lenne megmondani, hogy Magyarország ebből a szempontból hol áll, de erről semmiféle tudásunk nincs.

Magyarországon a bölcsődei, óvodai és általános iskolai pedagógusok kb.70-75\%-ának szürése azt az eredményt hozta 2020 novemberében, hogy a fertőzöttség a körükben $2,5 \%$ alatt van. De hazánkban a mintegy egymillió gyermeket, akik még bejárnak ezekbe az intézményekbe, nem tesztelték, így nehéz bármit is állítani arról, hogy a gyermeknevelési intézmények járványgócpontoknak tekinthetők-e. A helyzetet súlyosbítja, hogy ezekben az intézményekben nincs következetes, kötelező kontaktkutatás, nem történik meg általában a fertőzöttek környezetében (kontaktjai körében) a tesztelés. Az oktatásinevelési intézményekben akkor lehet jobb a helyzet, ahogy ezt a finn példa is mutatta, ha a pedagógusok, az intézményvezetés tagjai következetesen betartják, betartatják a 
szabályokat, a fertőzés megjelenésekor komoly kontaktkutatás történik, intenzív teszteléssel, karanténnal. Ha biztosítani lehet, hogy a pedagógusok és a közvetlenül hozzájuk tartozó csoportjaik „viszonylag zárt rendszerben” legyenek jelen az intézmény falai között, akkor a járvány kisebb „betörése” kezelhetővé válik, nem okoz tömeges fertőzést, ami annak a biztosítéka, hogy az intézmény ne váljék a befoglaló közösség számára fertőzési gócponttá.

\section{A tanulás, tanítás megszakítatlan folytatása}

Az iskolák bezárása a tanítás-tanulás digitális munkarendben való folytatásával járt együtt. A döntéshozók, ahol az iskolák bezárása megtörtént, a világ országai döntő többségében az oktatás valamilyen formában történő folytatása mellett döntöttek, ez az esetek túlnyomó többségében a digitális eszközök, az internet felhasználásával történő oktatást (online oktatás, távolléti digitális oktatás) jelentette. Magyarországon az iskolabezárás március 13-án, pénteki napon történt elrendelését követően, hétfőn az iskolában a tanulóknak nem kellett már megjelenniük, és gyakorlatilag elkezdődött a távolléti oktatás.

A tapasztalatok szerint a pedagógusok többségének első reakciója az ijedtség volt, ám ez meglepően rövid ideig tartott, $\mathrm{s}$ a kezdeti zavarodottság felett hamar úrrá lett a tenni akarás, az alkalmazkodni akarás, egyáltalán az oktatás egészen új és különleges körülmények között történő megszervezéséhez kapcsolódó kötelességérzet. A legtöbb oktatási intézményben valóban napok alatt kialakították a pedagógusok az oktatás módjait. A lázas tenni akarás érthetően némileg eltakarta azokat a problémákat, amelyek az indulást követő hetekben fokozatosan egyre nyilvánvalóbbá váltak. Milyen problémák jelentkeztek?

- Elég hamar világossá vált, hogy a tanulók egy nem elhanyagolható hányada esetén nem lehet számolni azzal, hogy az online oktatásban részt tudnak venni, egyszerüen a megfelelő eszközök és az internetkapcsolat hiánya következtében (Hermann 2020; Osváth-Papp Z. 2020; Szülöi összefogás-AHang 2020).

- Kiderült, hogy számos családban nincs annyi digitális eszköz, amennyire a gyerekek tanulásához és a szülők esetleges távmunkájához szükség lenne. Egy kutatásban (Fekete-Porkoláb 2020) mintegy 25\%-nak adódott azon tanulók (közoktatás és felsőoktatás együtt) aránya, akik a családban másokkal együtt használtak digitális eszközt.

- A szokásos iskolai értékelési módok (feleltetés, dolgozatírás) alkalmazása könnyen érthető okokból rendkívül nehézzé vált (Huber-Helm 2020).

- Az osztálytermi körülmények között alkalmazott módszerek - egyszerüen átvíve azokat az online oktatás körülményei közé - még kevésbé kötötték le a tanulók figyelmét, mint az osztályteremben. Bár több kutatási beszámoló is kiemeli, hogy a pedagógusok igen nagy arányban használtak komplexebb online oktatási platformokat (pl. Czirfusz-Misley-Horváth 2020; Fekete-Porkoláb 2020), azonban a tapasztalatok szerint e programcsomagok komplex szolgáltatásainak igénybevételére csak ritkán került sor.

- Nem kevés pedagógus volt, aki pusztán kiadta házi feladatként a gyerekeknek a tankönyvbeli „lecke” elolvasását, „megtanulását”, vagy/és kijelölte a gyakorlásra szánt feladatokat, és formális, szummatív módon próbálta meg értékelni a gyerekek így megszerzett tudását (Osvátb-Papp Z. 2020; Fekete-Porkoláb 2020). Egy kutatásból 
az derült ki, hogy az iskolai tanulók, felsőoktatási hallgatók mintegy 42,4\%-a e-mailben tartotta a kapcsolatot tanáraival és diáktársaival (Huawei Technologies Hungary 2020). A Szülői összefogás és az AHang (2020) felmérése szerint a digitális oktatásba bekapcsolódó tanulók több mint egyötödének nem voltak online tanórái.

- Gyakran szakították meg a kapcsolatokat technikai problémák, amelyek fellépésében nem egyszer a gyerekek vagy a pedagógusok nem kellő digitális felkészültsége játszott szerepet.

- A járvány alatti online oktatásban a körülmények miatt az ilyen jellegű tanításitanulási folyamatok szervezése során élvezhető előnyök alig mutatkoztak (pl. az ilyen oktatás olcsóbb volta, sokkal flexibilisebb jellege), míg a „normál körülmények között” jól kompenzálható potenciális hátrányai erősen érvényesültek (pl. kooperatív munka szervezésének nehézségei, a kommunikáció korlátozottsága, a fizikai testekkel, anyagokkal, rajzokkal stb. végzett közös munka nem lehetséges volta).

A digitális oktatás feladatait elsősorban azok a pedagógusok tudták tartalmasan, nagy veszteségek nélkül megoldani, akik a tanulásról és a tanításról korszerű elképzeléseket vallottak már korábban is, és gyakorlatukat is azoknak megfelelően alakították. Az tudott jobban megbirkózni a nehézségekkel, aki a következő elvek szerint formálta már korábban is a tanító tevékenységét (egyszerüsítő megnevezéssel ezeket nevezhetjük a korszerü pedagógiai kultúra fontosabb alapelveinek):

- a tanulók nem egyszerü befogadói az ismereteknek, hanem aktív tudáskonstruktőrök;

- kiemelt szerepe van az önszabályozott tanulásnak;

- az esélyegyenlőtlenségek kialakulásának megelőzése érdekében a pedagógusnak, a tanítás-tanulás folyamatának alkalmazkodnia kell a tanulócsoportok és az egyes tanulók igényeihez és sajátosságaihoz;

- az érdemi pedagógiai differenciálás, a személyre szabott oktatás kialakítása a tanításitanulási folyamatok alfája és ómegája;

- a tanulás társas tevékenység, az együttműködés jelentős szerepét kell biztosítani;

- a konstruált tudás adaptivitása és az ezen alapuló motiváció kritikus eleme a sikerességnek a tanulásban (csak a legfontosabbakat említve).

Minden a magyar oktatási rendszerről alkotott ismeretünk szerint a magyar oktatási rendszerben a felsorolt pontok mögött álló, most csak egyszerüen korszerünek nevezendő pedagógiai kultúra jelen van ugyan, de igen távol van attól, hogy domináns legyen. A tanulási-tanítási folyamatokkal összefüggő oktatáspolitikai kérdéseket elöször e ponton kell felvetnünk. A korábbi időszakok, így elsősorban a megelőző három évtized fejlesztéspolitikája marasztalható el azzal összefüggésben, hogy a magyar közoktatás a pedagógiai kultúra állapotát tekintve nem várhatta felkészülten a járvány kitörését (hasonló következtetésekre jutott Jakab György [2020] is).

$\mathrm{Ez}$ azt eredményezte, hogy a pedagógusok többségének esetében a hagyományos pedagógiai kultúra jellemezte alapvetően a digitális eszközök használatával zajló tanítást és tanulást. A videokonferencia-platformokon is domináns szerepe volt a frontális tanulásszervezésnek. Az osztályteremben alkalmazott eljárások mint „online tanítási módszerek" jelentek meg, és természetesen sok volt a panasz, hogy milyen nehéz így tanítani. A pedagógiai értékelés sem volt más - a tapasztalatok szerint -, mint amit a tanulók az osztálytermi oktatásban mindig is megtapasztalhattak. Minden ugyanúgy 
zajlott, mint amikor nem volt járvány. Vagyis, hogy zajlott volna, hiszen a hagyományos pedagógiai kultúra elemei valójában nem kompatibilisek az elektronikus tanulási környezetek alkalmazásával. A Szülői összefogás és az AHang (2020) felmérése szerint a szülők háromnegyede úgy ítélte meg a helyzetet, hogy gyermekük tanulásának nagy része lexikális tananyag elsajátítását jelentette. ${ }^{5}$ Nagy Ádám és Fekete Mariann egy elemző tanulmányban szintén arra hívják fel a figyelmet, hogy a digitális oktatás - annak komplex, korszerü értelmezése szerint - egészen mást jelent, mint egyszerüen a hagyományos módszerek „képernyőre vitelét” (Nagy-Fekete 2020).

Természetesen voltak, vannak alternatívák. Le lehet mondani a tanítás-tanulás kötött órarendi keretek közötti megszervezéséről, vagyis egyhetes, kéthetes időbeosztásban lehet a munkát megszervezni, illetve témákra osztott módon komplexebb feladatok kiadásával. Erősen építeni kell a gyerekek közötti, maguk irányította online kapcsolattartásra és így a páros és a csoportmunkák szervezésére. Projektszerű feladatokat kell kiadni, illetve a tanulókkal közösen projektekben kell megszervezni a tanulást. A pedagógus kapcsolattartása a tanulókkal a segítést, a konzultálást jelenti, az értékelés pedig alapvetően az elkészült tanulói produktumok tartalmi, szöveges értékelése, a minőség megbeszélése, illetve alapvető szerepet kap az értékelésben a párok, csoportok és az egyes tanulók önértékelése. A kiadott feladatok tartalmával megoldható a differenciálás is. A gyerekek, fiatalok munkáját lehet segíteni források rendelkezésre bocsátásával, kisebb ötletek adásával, tájékozódási lehetőségekre való figyelemfelhívással, illetve a ma már nagy számban rendelkezésre álló, az interneten elérhető oktatási szoftverek alkalmazására való ösztönzéssel. Világos, hogy az ilyen tanulásszervezés gyökeresen eltér attól, ahogyan egy hagyományos pedagógiai kultúrában megszerveződő tanóra felépül.

Nagyon sokan hiszik, hogy a „digitális átállás”, vagyis az eszközhasználat megtanulása jelentette a fó nehézséget (Osváth-Papp Z. 2020). Ez azonban nagy valószínűséggel nem így van. A probléma mélyebben volt. Az igazi nehézséget a pedagógiai kultúra elmaradottsága jelentette. A pedagógusok nagy része az osztálytermi körülmények között gyakorolt módszereit alkalmazta a digitális környezetben, és ebből eleve nem sülhetett ki semmi jó. Akik már az osztálytermi körülmények között is egy másfajta, jóval korszerübb pedagógiai kultúra elveit és gyakorlati megoldásait követték, viszonylag könnyen alkalmazták módszereiket az online oktatás körülményei között is. A határvonal tehát nem a digitális pedagógiában jártasak és nem jártasak között húzódott, hanem sokkal inkább a hagyományos pedagógiai kultúrát elhagyni képtelen és az abból már kilépett szereplők között.

Mik ennek a helyzetnek az oktatáspolitikai tanulságai? A járvány okozta válságban az oktatás problémáinak megoldása sokkal sikeresebb lehetett volna, ha az oktatási rendszer pedagógiai szempontból felkészülten kerül szembe a kihívásokkal. Ez meggyőződésem szerint - azt jelentette volna, hogy Magyarországon a korszerűként elfogadott pedagógiai kultúra van domináns szerepben. Hogy országunk nem ebben az állapotban látott neki a járvány okozta súlyos problémák megoldásának, annak egyértelműen az oktatás modernizációjának az elmaradása a legfőbb oka, vagyis itt súlyos

5 A járvány kitörése után közvetlenül végrehajtott felmérések nagy részének van egy viszonylag jelentős hiányossága: e kutatások során a minták reprezentativitását szinte lehetetlen volt biztosítani. A különleges helyzetben, tekintetbe véve a gyors tájékozódás iránti igényt is, ezt szinte természetesnek vehetjük. Az ily módon nyert információk közül elsősorban azok a nagyobb biztonsággal felhasználhatók a tájékozódásban, amelyekben szélsőséges adatok adódtak. 
oktatáspolitikai problémahalmazzal kell szembenézni. A következőkben azt mutatom be, hogy a tudományos felismerések az oktatáspolitika milyen lépéseinek, döntéseinek, programjainak adaptív voltát támasztják alá és melyeket kérdőjelezik meg. Ez alapján igyekszem kimutatni, hogy Magyarországon az oktatásnak valóban egy modernizációs válsággal kell szembenéznie. Tudományos evidenciáknak tekintem a következőket:

- Az oktatási rendszerek intézményi, igazgatási, gazdasági és pedagógiai szakmai (tartalmi) centralizációja csak átmenetileg játszhat pozitív szerepet a rendkívül kaotikus állapotban lévő oktatási rendszerekben, egyébként a szubszidiaritás elvének érvényesítése esetén várható, hogy egy oktatási rendszer alkalmazkodóképes lesz, és képes a megújulásra. Magyarországon az oktatásban sem 2010-ben sem azt megelőzően nem voltak kaotikus állapotok.

- Az oktatási rendszer eredményes működésének - amennyiben a rendszer egyensúlyi és nem kaotikus állapotban van - az egyik legfontosabb garanciája az intézmények és a pedagógusok nagyfokú szakmai autonómiája.

- Az oktatás modernizációja az ezredfordulón és az azt követő évtizedekben a korszerü pedagógiai kultúra (korszerű tanulás és tudásfelfogás, önszabályozott tanulás, adaptivitás, differenciálás, az esélyegyenlőtlenségek kialakulásának megelőzése, kooperativitás stb.) elterjesztését, fokozatosan dominánssá tételét jelenti.

- Az oktatás modernizációját szolgáló folyamatokhoz mély szakmai-tudományos megalapozottsággal bíró, a korszerủ kutatás-fejlesztés követelményeinek megfelelően kidolgozott programokra van szükség. E programok kialakítása esetén alapvető szerepe van annak, hogy maguk a pedagógusok is aktív, alkotó résztvevői legyenek e munkálatoknak. Az innovációs tevékenység egy messze nem elhanyagolható hányadának helyi, intézményi innovációnak kell lennie.

- Az oktatás modernizációja számára erős támogatást jelent egy fejlesztő típusú, alapvetően az intézményekre koncentráló, a belső értékelési folyamatokat, valamint államilag fenntartott, de szakmailag független külső értékelési szervezet által végzett tevékenységet preferáló tanfelügyeleti rendszer kialakítása és müködtetése.

Ezeket a tudományos kutatások során számtalanszor és szinte ellentmondásmentesen megerősített alapelveket, vagyis az oktatási modernizáció kibontakozásának alapvető összetevőit vizsgálva Magyarországon, az elmúlt harminc év folyamatait tekintve az első húsz évben sok problémával küzdő, ellentmondásos nekirugaszkodásokat tapasztaltunk. Idesorolom például az iskolafenntartás, -irányítás 1993-ban bekövetkezett nagyfokú demokratizálását, amely azonban létrehozott egy túlságosan széttagolt fenntartói struktúrát. A szakképzés különböző reformjai 1990 és 2010 között hordoztak magukban előremutató elemeket (például a közismereti képzés erősítése), ám nem tudtunk előrelépni az iskolarendszernek a szakképzést leginkább sújtó, ósdi szisztémájának átalakításában, a szelekció csökkentésében. Kialakítottuk 1995-re a kétpólusú tantervi, tartalmi szabályozást, fontossá vált az oktatási intézmények önálló tervező munkája, de egyrészt nem tudtuk erős szakmai eszközökkel segíteni a helyi érdemi tervezés kialakítását, másrészt a nem előíró, nem merev Nemzeti alaptanterv (NAT) mellett 2001-ben megjelentek az elöíró, az iskolában érvényesítendő tartalmat mereven megszabó kerettantervek. 2005-től az Európai Uniótól érkező forrásokra alapozottan reményt keltő fejlesztési folyamatok indultak el és hoztak részsikereket. Fontos volt ebből a szempontból a kompetenciafejlesztő programcsomagok megalkotása, az Országos 
Oktatási Integrációs Hálózat, valamint az Integrációs Pedagógiai Rendszer működése, a helyi kezdeményezések, a jó gyakorlatok elterjesztése érdekében horizontális hálózatok formálódása. E fejlesztési folyamatok önmagukban sem voltak mentesek minden ellentmondástól, azonban kivétel nélkül, minden kezdeményezés, amely a 2010 előtti időszakban a modernizáció elindulásának reményét keltette, 2010-et követően nagyon rövid időn belül elenyészett. 2013-tól az oktatási intézmények fenntartását, irányítását teljes mértékben központosította az állam, az iskolák elveszítették gazdasági, szervezeti és szakmai önállóságuk legtöbb elemét. Teljes mértékben központosított, részletesen előíró Nemzeti Alaptanterv és kerettantervek születtek (2001, 2012 és 2020). A tartalmi szabályozás maga így a személyre szóló fejlesztés, az érdemi pedagógiai differenciálás és a helyi innovációk kialakításának legfőbb gátjává vált. Az oktatásfejlesztésre rendelkezésre álló hatalmas összegek döntő hányada központi szervezési feladatokra (elsősorban az új irányítási struktúra kialakítására) lett fordítva, a helyi innovációk lényegében megszüntek.

A COVID-válság kialakulásának küszöbére a magyar oktatás ebben az állapotban, egy elmaradt modernizáció minden visszamaradottságát és feszültségét magában hordozva jutott el. Az oktatásirányításnak nem állt szándékában az oktatás modernizációjának szükségleteiből kiindulva a korszerü pedagógiai elvek alapján megoldani a COVID-járvány keltette válságot. Megoldásként, a hagyományos pedagógiai kultúrához ragaszkodva tesz, tett bizonyos lépéseket, illetve éppen a korszerű pedagógiához való ellentmondásos viszonya gátolta meg abban, hogy indokolt, a modernizáció elveivel összhangban álló intézkedéseket hozzon.

De mégis, mi az, ami valójában történt? A pedagógusok körében általános megítélés, hogy az oktatási kormányzat valójában magukra hagyta az iskolákat a járvány hatásaival való megküzdés és különösen a digitális oktatás kialakítását kísérő problémák megoldásával kapcsolatban. Természetesen az nem igaz, hogy semmi nem történt az iskolák segítése érdekében. Érdemes a fontosabb részleteket felidézni és elemezni.

a) Az Oktatási Hivatal mindenekelőtt bizonyos tanácsokkal látta el az iskolákat. E tanácsok nagy része az oktatás megszervezésével van kapcsolatban, és nagy valószínűséggel az iskolák nagy része számára nem jelentett különösebb újdonságot.

b) A Hivatal tanácsokat ad az online oktatás kivitelezésének bizonyos szoftver jellegü feltételeivel kapcsolatban, platformokat, elektronikus oktatásszervezési keretrendszereket ajánl. Nem fölöslegesek természetesen ezek az információk sem, de az ismert lehetőségek megemlítésénél sokkal többre lenne szükség.

c) Külön ki kell emelni, hogy a Hivatal egy általános oktatásszervezési keretrendszerként, a tanulás szervezésére, adminisztrációra, házi feladatok adására, informálásra és értékelésre is használható rendszerként ajánlja a Kréta szoftverrendszert, amelyről az iskolabezárást követő napokban gyorsan kiderült, hogy nem bírja a nagy terhelést, és a pedagógusok, akik egyáltalán elkezdték alkalmazni, többségükben lemondtak a használatáról (Osvátb-Papp Z. 2020).

d) Volumenében a legjelentősebb segítség a digitális oktatás szervezéséhez a Nemzeti Köznevelési Portálon keresztül volt elérhető. A hagyományos módszerekkel zajló, de az önálló (elsősorban egyéni) tanulás segítésére az Oktatási Hivatal által rendelkezésre bocsátott okostankönyvek jelentették és jelentik a leginkább célzott segítséget ${ }^{6}$

6 https://www.nkp.hu/okostankonyvek 
(a tantervben is szereplő témákra vonatkozó, a hivatalos tankönyvek „okosításával” létrejött internetes eszközök, tankönyvi „leckék” képi, hang alakú és filmes szemléltetéssel, gyakorló feladatokkal). Ez a támogatás szakmai jellegét, irányultságát tekintve nem távolodik el a hagyományos megoldásoktól, ugyanis a rendelkezésre bocsátott okostankönyvek is pusztán szemléltetnek, szövegtanulást és típusfeladat-megoldást igényelnek. Tudáskonstruálás helyett memorizálást (biztos, hogy sok esetben biflázást). A differenciálásnak nyoma sincs, és annak kialakítása az okostankönyvek használatával a pedagógusok számára rendkívül nehéz feladat. Csoport- és pármunka ugyan szervezhető, de a komplexitás hiánya miatt a feladatok valójában e szervezési módok alkalmazására nem megfelelők. A motiváció létrejötte esetleges. A tudás adaptivitásáról a tanulók „meggyőzését” nem szolgálja lényegében semmi. Vagyis az okostankönyvek csak az önszabályozott tanulás terén jelentenek némi előrelépést. Ott sem nagyot, hiszen a leckék nem tartalmaznak olyan elemeket, amelyekben megjelenne a diákok tanulásra történő tanítása. A portál ezentúl letölthető anyagok, valójában a központi fejlesztésben előállított tankönyvek elektronikus változatait kínálja. Egy médiatár található az oldalon, amely filmeket, térképeket és hanganyagokat tartalmaz, valamint egy feladattár van még itt. Ezek a tartalmak mind hagyományos pedagógiai eszközök, igaz, a filmek és a hanganyagok korszerü pedagógiai alapon megtervezett oktatási programok részeként is felhasználhatók. A portál azonban közvetlenül nem nyújt jelentős segítséget a pedagógusoknak a korszerü módszereket alkalmazó tanítási-tanulási folyamatok kialakításához. Tanulásszemléletét tekintve a szemléltetés pedagógiájáig jut el. A tanulók önálló tevékenységeire építkező, a cselekvés pedagógiájának megfelelő tanuláselképzelés érvényesítése során nem használható jól, illetve, ha valaki a konstruktivista pedagógia alapelveinek megfelelően szeretne tanítani, akkor szinte egyáltalán nem tudja igénybe venni a portál szolgáltatásait.

e) Az oktatási kormányzat az Oktatási Hivatalon keresztül segítséget kívánt nyújtani a pedagógusoknak a digitális oktatás során felhasználható, az interneten elérhető oktatási programok listáinak, linkgyüjteményeinek a közzétételével. A tapasztalat azt mutatta, hogy a linkgyüjtemények természetesen hasznosak, azonban használatukhoz egyrészt szükséges, hogy a pedagógus egyáltalán akarjon felhasználni internetes tartalmakat az oktatás során, másrészt a sok linkgyüjtemény használata nehéz feladatnak bizonyult. Szinte minden ilyen gyüjteményben szép számmal jelentek meg nem ingyenes, nagyon nehezen kereshető, kis oktatási relevanciával bíró termékek is, a linkgyüjtemények „erősen szennyezettek” voltak, többségükben nem strukturáltak, egy minimális digitális kompetenciával rendelkező pedagógus számára általában nehezen használhatók. Vagyis az oktatásirányítás által nyújtott, a digitális oktatás kialakítása, szervezése során használható segítség rendkívül erősen kötődött, és mai állapotában is kötődik a hagyományos pedagógiai kultúrához.

f) Volt-e ennek alternatívája? Azt nem lehet mondani, hogy minden pedagógusnak az volt az igénye, hogy támogatást kapjon hagyományos módszereinek alkalmazásához. Az sem igaz, hogy az igény a korszerű pedagógiát képviselő támogatás iránt a pedagógusok egy ugyan korlátozott, de nem elhanyagolható körében ne lett volna meg. A korszerű pedagógiai kultúrának van képviselete a hazai pedagógiában, még ha ez a képviselet kisebbségi is. Lehetőség volt arra, hogy a korszerü tanulásfelfogás szerint, korszerü módszerekkel tanító pedagógusokat segítse az oktatásirányítás a szakmai szervein keresztül. A tanórákon való részvételre és a formális értékelésre 
vonatkozó központi előírások merev betartása esetén ezek a pedagógusok inkább a gátlást és nem a támogatást kellett, hogy megéljék. Természetesen jó lett volna, ha rendelkezésre álltak volna, állnának olyan kidolgozott oktatási modulok, amelyek a korszerü látásmódnak és gyakorlatnak felelnek meg. ${ }^{7}$ Vagyis a jó gyakorlatok következetes, nagy volumenű terjesztésére lett volna szükség. Némi terjedés megfigyelhető volt, így például a közösségi médiában néhány pedagógus tett közzé óraterveket, projektterveket, csoportmunka-feladatokat és más leírásokat a lehetséges megoldásokra, azonban nagyléptékű megosztó rendszer nem alakult ki. Ennek kezdeményezése, intézményi és financiális feltételeinek megteremtése eminens oktatásirányítási feladat lett volna, ám ennek vállalása nem történt meg.

\section{Esélyegyenlőtlenség}

Magyarországon is igaz, mint ahogy az egész Földön (Doyle 2020), hogy a társadalmi okokból, vagy más, tőlük független okból hátrányos helyzetü gyerekek elmaradása a tanulásban a COVID-19-járvány ideje alatt sokkal jelentősebb, mint jobb sorban élő társaiké. Tegyük ehhez hozzá, hogy a rosszabb helyzet nem pusztán a tanulmányok terén érhető tetten: a hátrányos helyzetű gyerekek egészségügyi ellátása, az étkeztetés, családjaik átlagosnál valószínüleg rosszabb helyzete a járvány alatt, a környezettől való elzártság nagyobb foka, a kommunikációs eszközök valószínübb hiánya további súlyos problémákat okozott (Masonbrink-Hurley 2020). Jelentősen gátolta a járványhelyzet a gyermekvédelmi szolgálatok tevékenységét. Bár a működésük nem állt le, de a közvetlen kapcsolattartásnak a krízishelyzetekre való leszükítése, az ügyek távolról való intézése sok komoly probléma forrása volt ezen a területen is. A hátrányos helyzetű gyermekek a járvány ideje alatt kitettebbek lehetnek az ún. rizikómagatartások kockázatának (Holle 2020). Az egyik legsúlyosabb negatív következménye lehet a járvány következtében kialakult oktatási helyzetnek a korai iskolaelhagyás, a lemorzsolódás arányának növekedése, amiben még olyan tényezők is szerepet kaphatnak, mint a túl korai gyermekvállalás számának növekedése a pandémia ideje alatt.

$\mathrm{A} z$ esélyegyenlőtlenségi helyzet értékelése szempontjából a legjelentősebb kérdés, hogy a diákok közül kiknek (arányok, társadalmi, családi helyzet, más jellemzők) sikerült bekapcsolódni a távolléti oktatásba, és ez a bekapcsolódás milyen mértékü, milyen intenzitású volt. Több vizsgálat igyekezett megbecsülni azoknak a tanulóknak a számarányát, akik nem tudtak bekapcsolódni az online oktatásba (Czirfusz-Misley-Horváth 2020; Hermann 2020; Osvátb-Papp Z. 2020). E tanulmányokban szereplő becslések alapján nehéz lenne akárcsak kicsit is pontos arányszámot mondani, de talán nem állok messze a valódi értéktől, ha azt mondom, hogy a közoktatásban a tanulóknak kb. a 15-20\%-a egyáltalán nem, vagy csak minimális mértékben tudott részt venni az oktatás ezen formájában. Az országos (erősen becsült) adat mögött jelentős területi különbségek vannak, az ország hátrányos helyzetű térségeiben az adatok sokkal rosszabbak,

\footnotetext{
A felkészülés problémáit jól mutatja, hogy a Digitális Oktatási Stratégiában megfogalmazott feladatok elvégzése, a „termékek” megjelenése igencsak jelentős segítséget jelentett volna a járvány kitörésekor, azonban a Stratégiában szereplő feladatok végrehajtása nem történt meg az eredetileg megszabott határidőkre (a Kréta rendszer felállításán kívül). Valójában ma sem tudjuk, hogy a DOS-ban leírt, egyébként a megfogalmazások szintjén nagyon is elöremutató, korszerü törekvések egyáltalán érvényesülhetnek-e.
} 
illetve a hátrányos helyzetű társadalmi csoportokat sokkal erősebben sújtották e problémák (Hermann 2020).

Természetesen a pedagógusok az országban a digitális eszközök hiánya esetén is tettek erőfeszítéseket a tanulók bevonására (pl. feladatok postán való eljuttatása, házhoz „szállítása”, a gyermekjóléti szolgáltatások lehetőségeinek igénybevétele), de ennek sikerével, mértékével összefüggésben még kevesebb információval rendelkezünk, mint a digitális oktatásban résztvevőkkel kapcsolatban.

A számítógépes eszközökkel vagy/és interneteléréssel nem rendelkező tanulók segítése állami intézkedéseket igényelt volna. A világ számos országában ilyen intézkedéseket hoztak a kormányok a TV-k, rádiók bevonásával kapcsolatban, munkalapok, feladatok nyomtatására és tanulókhoz való eljuttatására vonatkozóan, előfordult digitális eszközök kölcsönzése, néhány afrikai országban nagy elektronikai cégeket nyertek meg a kormányok a segítségnyújtásra. Magyarországon ezek közül egy komolyabb lépés történt, mégpedig az M5 televízió tanulást segítő műsorainak a sugárzásával, valamint online elérhetővé tételével. Bár - a szerző benyomása szerint - e műsorok jó színvonalúak, és nyilván a semminél sokkal többet jelentenek, azonban pedagógiai szempontból, már csak a müfaj természetéből adódóan sem juthatnak túl a szemléltetés pedagógiáján. Vagyis általában igaz lehet, hogy az online oktatástól eltérő megoldások pedagógiai színvonala szükségképpen alacsonyabb, mint amilyen színvonalat el lehet érni az online oktatással. E megoldásokat pedig inkább a hátrányos helyzetű tanulók kellett, hogy igénybe vegyék.

Mi lesz a következménye mindennek? Régi pedagógiai tapasztalat, hogy a gyerekek kimaradása az iskolai tanulás folyamataiból, ha az hosszú ideig tart (legalább egy hónap) komoly, nagyon nehezen behozható lemaradásokat okoz. Az is tapasztalat, de sok kutatás eredményével is alátámasztott ismeretünk, hogy a kéthónapos nyári szünet majdnem minden gyermek számára észrevehető „tudáscsökkenést” jelent (sok ismeret elfelejtése, készségek, képességek nem elhanyagolható mértékű visszafejlődése). Mindezen ismereteink alapján komoly gondokkal kell számolni azoknál a tanulóknál, akik nem tudtak intenzíven bekapcsolódni a pandémia alatt a tanulási folyamatokba. Nyilvánvaló, hogy e csoportban erősen túlreprezentáltak a szociálisan, vagy más, tőlük független okokból hátrányos helyzetű gyerekek. A hatásokat kimutatni ma még nem tudjuk, 2020-ban nem volt Országos kompetenciamérés sem éppen a járvány miatt. A 2021-es eredmények majd mutathatnak valamit, feltéve, hogy jövőre már le lehet bonyolítani a mérést. Sajnos az várható, hogy minden tanulói csoport gyengébben teljesít majd a korábbi évek színvonalához képest, de az is várható, hogy tovább nő majd a különbség a hátrányos helyzetü gyerekek, valamint a náluk jobb élethelyzetben lévők teszteredményei között.

\section{IRODALOM}

Auger, K. A., Shah, S.S., Richardson, T., Hartley, D., Hall, M., Warniment, A., Timmons, K., Bosse, D., Ferris, S. A., Brady, P. W., Schondelmeyer, A. C. \& Thomson, J. E. (2020) Association between Statewide School Closure and COVID-19 Incidence and Mortality in the US. JAMA, Vol. 324. No 9. pp. 859-870.

Birnbaum, M. (2020) Europe Schools Still Open, Still Relatively Safe, through Covid-19 Second Wave. The Washington Post, Dec. 1, 2020. 
Czirfusz D., Misley H. \& Horváth L. (2020) A digitális munkarend tapasztalatai a magyar közoktatásban. Opus et Educatio, Vol. 7. No. 3. pp. 220-229.

Doy le, O. (2020) COVID-19: Exacerbating Educational Inequalities? Dublin, University College Dublin. https://publicpolicy.ie/papers/coviD-19-exacerbating-educationalinequalities/ [Letöltve: 2020.08,01.]

Fekete T. \& Porkoláb Á. (2020) Karanténpedagógia a magyar közoktatásban - A digitális oktatásra történő átállás eddigi tapasztalatairól. Iskolakultúra, Vol. 30. No. 9. pp. 96-112.

Hermann Z. (2020) Hány diákhoz nem jut el az online oktatás? Budapest, Közgazdaság- és Regionális Tudományi Kutatóközpont Közgazdaság-tudományi Intézete. https://www. mtakti.hu/koronavirus/hany-diakhoz-nem-jut-el-az-online-tavoktatas/12769/ [Letöltve: 2020. 08. 10.]

Holle A. (2020) Oktatási rendszerek az új koronavírus járvány idején. Budapest, Országgyülés Hivatala.

Huawei Technologies Hungary (2020) A diákok tizede örökre online maradna suliba járás helyett. Budapest, Huawei Technologies Hungary. https://consumer.huawei.com/hu/ press/news/2020/news-200430/ [Letöltve: 2020.11.02.]

Huber, S. G. \& Helm, C. (2020) COVID-19 and Schoolingः Evaluation, Assessment and Accountability in Times of Crises - Reacting Quickly to Explore Key Issues for Policy, Practice and Research with the School Barometer. Educational Assessment, Evaluation and Accountability, No. 32. pp. 237-270.

Jackson, C., Mangtani, P., Hawker, J., Olowokure, B. \& Vynnycky, E. (2014) The Effects of School Closures on Influenza Outbreaks and Pandemics: Systematic Review of Simulation Studies. PLoS ONE, Vol. 9. No. 5. https://journals.plos.org/plosone/ article?id=10.1371/journal.pone.0097297 [Letöltve: 2020. 08. 10.]

Jакав Gy. (2020) ISKOLA - járvány idején (1. rész). Iskolakultúra, Vol. 30. No. 9. pp. 6476.

Lancker, W. V. \& Parolin, Z. (2020) COVID-19, School Closures and Child Poverty: A Social Crisis in the Making. Lancet Public Health (online). https://www. thelancet.com/journals/lanpub/article/PIIS2468-2667(20)30084-0/fulltext?utm_ campaign $=$ update-lanpub\&utm_source $=$ hs_email\&utm_medium $=$ email\&utm_ content $=88236179 \& \_$hsenc $=$p2ANqtz - cC6OC8_HyGNOKJgZaaKJrwZXAP2 ucPCPTyvdNdARaqiWqRb9Z-CfycUZm-gdbV1XIe1DVK3qqw088wbTyqR9uYgFme 1iABnJXJRc9AAWLCKJ4PauvGU4Ftcc]0f_EqL4aV64D\&_hsmi=88236179 [Letöltve: 2020. 09. 10.]

Masonbrink, A. R. \& Hurley, E. (2020) Advocating for Children during the COVID-19 School Closures. Pediatrics, Vol. 146. No. 3. (online) https://www.researchgate.net/ profile/Emily_Hurley2/publication/342248636_Advocating_for_Children_During_ the_COVID-19_School_Closures/links/5ef0b5e8a6fdcc73be94514a/Advocating-forChildren-During-the-COVID-19-School-Closures.pdf [Letöltve: 2020. 09. 21.]

Nagy Á. \& Fekete M. (2020) OK, Zoomer - a digitális tanulás problémái. Opus et Educatio, Vol. 7. No. 3. pp. 203-207.

Osvátr A. \& PApp Z. A. (2020) Digitális fordulat az oktatásban? A digitális távoktatás tapasztalatai, lehetséges következményei. In: Szabó-Tóth KInga és Szepessy Péter (eds) Látlelet a járványbelyzetröl. Miskolc, Miskolci Egyetem Bölcsészettudományi Kar, Alkalmazott társadalomtudományi Intézet. pp. 179-204.

Szülői összefogás és AHang (2020) Szülői vélemény a digitális oktatásról. Szülöi összefogás gyermekeink jövőjéért, AHang; Budapest. (online) https://docs.google.com/document/ d/e/2PACX-1vSihd04xyu6HXWzZiwrwqjLYZQ9-Q_OMGRLahg7AEzaqm1Kn31 
ZXNsb55UrckRGnrblAC5uoDutAHud/pub?fbclid=IwAR0ysp4sVDxLS58T-Zwa_ zzbW67kWFyenC2y8mJISovSXFHojf5-sUrVDOc\&urp=gmail_link [Letöltve: 2020. 08. 23.]

UNESCO (2020) Adverse Concequences of School Closurs. Paris, Unesco. (online) https:// en.unesco.org/covid19/educationresponse/consequences.

A cikk a Creative Commons Attribution 4.0 International License (https://creativecommons.org/licenses/ by/4.0/) feltételei szerint publikált Open Access közlemény, melynek szellemében a cikk bármilyen médiumban szabadon felhasználható, megosztható és újraközölhető, feltéve, hogy az eredeti szerző és a közlés helye, illetve a CC License linkje és az esetlegesen végrehajtott módosítások feltüntetésre kerülnek. (SID_1) 